\title{
76. Isolation and Regeneration of Protoplasts from Cultures derived from the Spermogonial State of Gymnosporangium asiaticum*)
}

\author{
By Yasuyuki Tetsuka and Keizo Katsuya \\ Institute of Agriculture and Forestry, University \\ of Tsukuba, Ibaraki 305
}

(Communicated by Naohide Hiratsuka, M. J. A., Nov. 12, 1983)

Since isolation of protoplasts from an yeast was reported by Eddy and Williamson, ${ }^{6)}$ protoplasts have been obtained from a number of fungi.5),11) Recently, fungal protoplasts have been used for physiological, biochemical and genetic studies. ${ }^{3)}{ }^{13}$ Studies on axenic culture of rust fungi are now in progress, ${ }^{9), 12)}$ but isolation and regeneration of protoplasts from cultures of rust fungi have not been reported yet. This is the first report on isolation and regeneration of protoplasts from axenic cultures of a rust fungus.

Materials and methods. Four cultures derived from the spermogonial state of Gymnosporangium asiaticum Miyabe ex Yamada were obtained from rust-infected leaves of Pyrus pyrifolia var. culta. ${ }^{13)}$ The cultures were maintained on test tube slants holding $10 \mathrm{ml}$ of "Medium IV" containing per liter, $\mathrm{NH}_{4} \mathrm{NO}_{3}, 412.5 \mathrm{mg}$; $\mathrm{H}_{3} \mathrm{BO}_{3}, 1.55 \mathrm{mg} ; \mathrm{MnSO}_{4} \cdot 4 \mathrm{H}_{2} \mathrm{O}, 5.575 \mathrm{mg} ; \mathrm{CaCl}_{2} \cdot 2 \mathrm{H}_{2} \mathrm{O}, 110 \mathrm{mg}$; KI, $0.2075 \mathrm{mg} ; \mathrm{MgSO}_{4} \cdot 7 \mathrm{H}_{2} \mathrm{O}, 92.5 \mathrm{mg} ; \mathrm{CuSO}_{4} \cdot 5 \mathrm{H}_{2} \mathrm{O}, 0.00625 \mathrm{mg} ; \mathrm{CoCl}_{2}$. $6 \mathrm{H}_{2} \mathrm{O}, 0.00625 \mathrm{mg}$; $\mathrm{Na}_{2}$-EDTA, $93.25 \mathrm{mg} ; \mathrm{Na}_{2} \mathrm{MoO}_{4} \cdot 2 \mathrm{H}_{2} \mathrm{O}, 0.0625 \mathrm{mg}$; $\mathrm{KH}_{2} \mathrm{PO}_{4}, 42.5 \mathrm{mg} ; \mathrm{FeSO}_{4} \cdot 7 \mathrm{H}_{2} \mathrm{O}, 69.5 \mathrm{mg} ; \mathrm{ZnSO}_{4} \cdot 4 \mathrm{H}_{2} \mathrm{O}, 2.15 \mathrm{mg}$; Mioinositol, $25 \mathrm{mg}$; Pyridoxine $\mathrm{HCl}, 0.125 \mathrm{mg}$; Glycine, $0.5 \mathrm{mg}$; Thiamine $\mathrm{HCl}, 0.025 \mathrm{mg}$; Nicotinic acid, $0.025 \mathrm{mg}$; Evans peptone, $1 \mathrm{~g}$; Difco yeast extract, $1 \mathrm{~g}$; Sucrose, $30 \mathrm{~g}$; 2,4-D, $1 \mathrm{mg}$; Kinetin, $0.1 \mathrm{mg}$ and Agar, $10 \mathrm{~g}$.

About one gram (fresh weight) of mycelia grown at $20^{\circ} \mathrm{C}$ in the dark for 15 to 60 days on Medium IV were harvested with a sterilized forceps on a steel sieve (35 mesh), washed with sterilized distilled water to remove agar, and then suspended in $10 \mathrm{ml}$ of a combined enzyme solution in a $100 \mathrm{ml}$ Erlenmeyer flask. The combined enzyme solution consisted of macerozyme R-10 $(5 \mathrm{mg} / \mathrm{ml})$, cellulase "Onozuka" $\mathrm{R}-10(20 \mathrm{mg} / \mathrm{ml})$, driselase $(10 \mathrm{mg} / \mathrm{ml})$ and $\beta$-glucuronidase $(0.06 \mathrm{mg} / \mathrm{ml})$ in $0.6 \mathrm{M}$ mannitol $(\mathrm{pH} 5.2)$. The $\mathrm{pH}$ of the solution was adjusted to $\mathrm{pH} 5.2$ with $0.1 \mathrm{~N} \mathrm{KOH}$ after ad-

*) Contribution no. 37, Laboratories of Plant Pathology and Mycology, Institute of Agriculture and Forestry, University of Tsukuba. 
dition of the enzymes. The flask was placed in an incubator at $20-23^{\circ} \mathrm{C}$ for $1.5-4.0 \mathrm{hr}$. The enzyme solution with the mycelia was filtered through the steel sieve to remove mycelial fragments, and the filtrate was centrifuged at least twice at $2500 \mathrm{rpm}$ for $5 \mathrm{~min}$ to remove the enzyme. Purification of protoplasts was carried out by the liquid-liquid two phase system consisting of $0.6 \mathrm{M}$ sucrose and 0.6 M mannitol described by Hashiba and Yamada. ${ }^{7)}$ After purification, appropriately diluted suspensions of protoplasts (ca. 2000/ plate) were incubated on a regeneration medium at $20^{\circ} \mathrm{C}$ in the dark. The regeneration medium consisted of the components of Medium IV in 0.6 M mannitol instead of distilled water and adjusted to $\mathrm{pH} 5.7$ with $1 \mathrm{~N} \mathrm{KOH}$ or $1 \mathrm{~N} \mathrm{HCl}$ before autoclaving at $121^{\circ} \mathrm{C}$ for $10 \mathrm{~min}$.

Pieces of rust mycelium derived from protoplasts and grown on the regeneration medium were observed by light and scanning electron microscopes, using the methods described by Naito and Onoe, ${ }^{10)}$ and Ando and Katsuya,' ${ }^{1}$ respectively.

Results. Mycelia from cultures of different ages were examined for protoplast production. Yields of the protoplasts were high $\left(3.0 \times 10^{5} / \mathrm{g}\right.$, f. wt. $)$ when 15 - to 30 -day-old colonies were used,

Table I. Culture conditions to release protoplasts from mycelia of Gymnosporangium asiaticum

\begin{tabular}{cccccc}
\hline \multicolumn{2}{c}{ Isolate } & $\begin{array}{c}\text { Culture age } \\
\text { (days) }\end{array}$ & $\begin{array}{c}\text { Incubation } \\
\text { time }(\mathrm{hr})\end{array}$ & $\begin{array}{c}\text { Incubation } \\
\text { temperature (C) }\end{array}$ & $\begin{array}{c}\text { Yield } \\
\text { (Protoplasts/g***) }\end{array}$ \\
\hline Gyf* & 11 & 15 & 2.0 & 23 & $3.0 \times 10^{5}$ \\
Gyf & 16 & $\prime \prime$ & $\prime \prime$ & $\prime \prime$ & $1.0 \times 10^{5}$ \\
Gyf & 11 & 25 & $\prime \prime$ & 20 & $4.5 \times 10^{4}$ \\
Gyf & 16 & $\prime \prime$ & 1.5 & $\prime \prime$ & $7.5 \times 10^{3}$ \\
Gyf & 16 & 30 & 4.0 & $\prime \prime$ & $5.0 \times 10^{4}$ \\
Gyf & 11 & $\prime \prime$ & $\prime \prime$ & $\prime \prime$ & 0 \\
Gyf & 16 & $\prime \prime$ & 2.5 & $\prime \prime$ & $1.0 \times 10^{5}$ \\
Gyw** 13 & $\prime \prime$ & 2.0 & $\prime \prime$ & 0 \\
Gyw & 82 & $\prime \prime$ & 1.5 & $\prime \prime$ & 0 \\
Gyf & 16 & 60 & 2.0 & & 11 \\
Gyf & 16 & $\prime \prime$ & & &
\end{tabular}

* Fluffy colony. ** Water-soaked colony. *** Fresh weight of mycelium.

although the yields showed variation (Table I). On the other hand, no protoplasts resulted from the 60-day-old colonies.

Release of numerous protoplasts was observed after incubation in the combined enzyme solution for 1.5-2.5 hr. However, prolonged incubation $(4 \mathrm{hr})$ did not produce protoplasts.

The size of purified protoplasts was $5.8-12.5 \mu \mathrm{m}$ (average: $9.0 \mu \mathrm{m}$ ) in diam (Fig. 1). The protoplasts were incubated on the 
regeneration medium in 21 petri dishes at $20^{\circ} \mathrm{C}$ in the dark. After six months 19 of the petri dishes were contaminated. One of the non-contaminated dishes had four rust colonies $5.3-7.5 \mathrm{~mm}$ in diam that were derived from the protoplasts (Fig. 2). The other dish had no organismal growth. The rust colonies consisted of filamentous and swollen hyphal layers (Fig. 3). The filamentous hyphal cells were $3.5-5.5 \mu \mathrm{m}$ in diam, but the swollen cells had considerable variation in diameter ranging from 7.5 to $25.8 \mu \mathrm{m}$. One nucleus was always observed in the filamentous and swollen cells (Figs. 4, 5). It was identical with the nucleus of the hyphal cells of the parent culture. In the swollen hyphal layer, short chains of swollen cells were observed and an unknown short isthmus-like structure was present between the cells (Fig. 6). A collar-like structure was occasionally observed on the basal cell of a chain of swollen cells (Fig. 7).

When regenerated colonies were transferred onto fresh Medium IV, hyphal strands occurred on the surface of the colonies about 1 month after transfer (Fig. 8). The hyphal strands consisted of filamentous and swollen hyphae in the upper and the basal parts, respectively. During successive transfers, the colonies (Fig. 9)

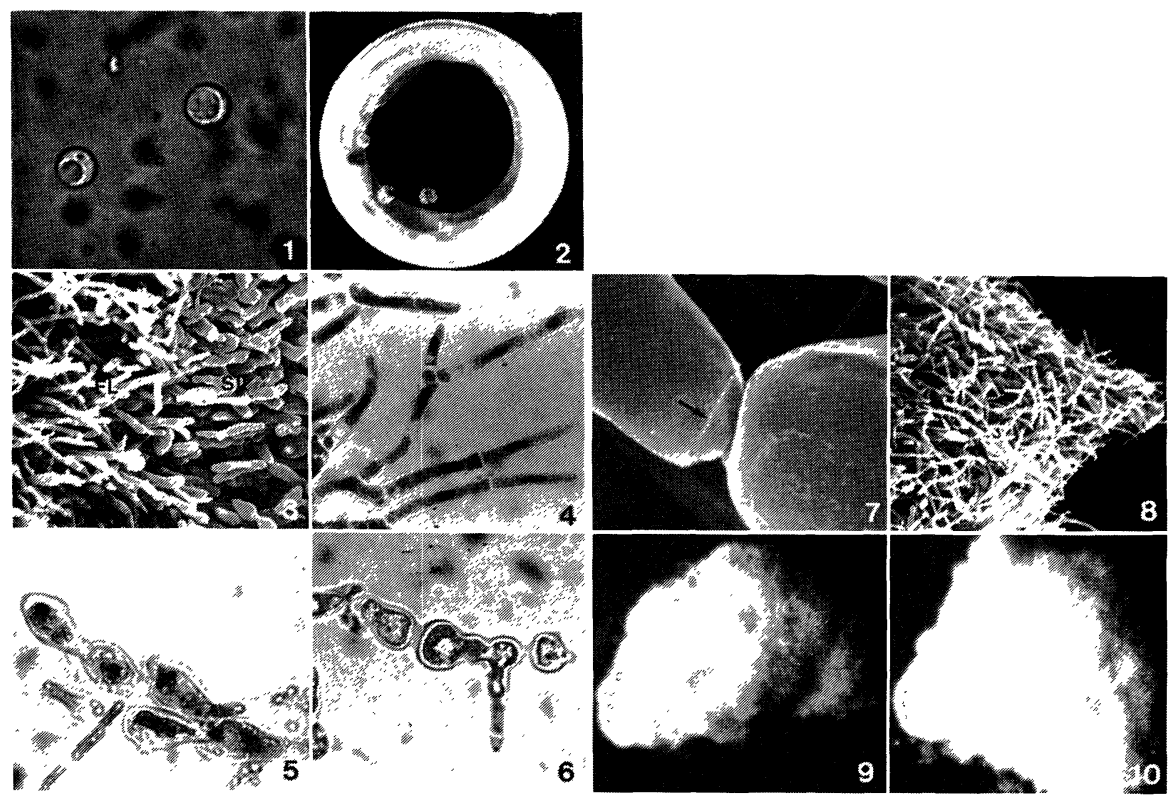

Figs. 1-10. 1: Protoplasts isolated from rust mycelia. 2: Colonies regenerated from protoplasts, 7 months after incubation. 3: Vertical section of the regenerated colony consisted of filamentous (FL) and swollen (SL) hyphal layers. 4: Filamentous hyphae with single nucleus. 5: Swollen cells with single nucleus. 6: Short chains of swollen cells. 7: A collar-like structure (arrow) observed in the basal cell of the chained swollen cells. 8: Hyphal strand. 9: Regenerated colony. 10: Parental fluffy colony. 
changed into the same fluffy type as the parental culture (Fig. 10).

Discussion. Age of mycelia and incubation time in a combined enzyme solution strongly affected protoplast isolation from cultures of Gymnosporangium asiaticum. These effects have been reported previously on Rhizoctonia solani ${ }^{7)}$ and on Schizophyllum commune. ${ }^{4}$ The results showed that 15- to 30-day-old colonies and about $2 \mathrm{hr}$ incubation in the combined enzyme solution are suitable to release protoplasts from the rust mycelium.

Hashiba and Yamada ${ }^{\tau}$ ) used a combined enzyme solution for releasing protoplasts from mycelia of $R$. solani with high yield $(6.6 \times$ $10^{7}$ protoplasts $\left./ \mathrm{g}\right)$. Using the same enzyme solution, we obtained a tolerable yield $\left(3.0 \times 10^{5} / \mathrm{g}\right)$ of protoplasts from mycelia of $G$. asiaticum. For obtaining a more suitable enzyme system to release protoplasts of rust fungi, it will be necessary to examine various kinds of enzyme and combinations of enzymes.

Usually, colonies of rust fungi grow very slowly on artificial media $^{2)}$ as compared with other fungi. Equally, it took a long time to regenerate protoplasts of $G$. asiaticum. To improve such studies, we need to find better media for regeneration of protoplasts from rust cultures.

G. asiaticum has two mating types, + and - in the spermogonial state. Protoplasts obtained from the different mating types may be useful for studies of cell fusion and sexual reproduction.

Acknowledgments. The authors wish to express sincere thanks to Drs. T. Hashiba, M. Yamada and H. Yaegashi, National Institute of Agricultural Sciences, for direction of technique and helpful suggestions throughout the experiment.

\section{References}

1) Ando, K., and Katsuya, K.: Proc. Japan Acad., 57B, 129-134 (1981).

2) —: Ann. Phytopath. Soc. Japan, 47, 637-645 (1981).

3) Anne, J., and Peberdy, J. F.: J. Gen. Microbiol., 92, 413-417 (1976).

4) de Vries, O. M. H., and Wessels, J. G. H.: J. Gen. Microbiol., 73, 13-22 (1972).

5) —-: Antonie Van Leeuwenhoek, 39, 397-400 (1973).

6) Eddy, A. A., and Williamson, D. H.: Nature, 179, 1252-1253 (1957).

7) Hashiba, T., and Yamada, M.: Phytopathology, 72, 849-853 (1982).

8) Kevei, F., and Peberdy, J. F.: J. Gen. Microbiol., 102, 255-262 (1977).

9) Maclean, D. J.: The Rust Fungi. Academic press, pp. 37-120 (1982).

10) Naito, N., and Onoe, T.: Ann. Phytopath. Soc. Japan, 37, 103-108 (1968).

11) Peberdy, J. F.: Ann. Rev. Microbiol., 33, 21-39 (1979).

12) Scott, K. J.: Physiological plant pathology. vol. 4, Encyclopedia of Plant Physiology, new series, pp. 719-742 (1976).

13) Tetsuka, Y. et al.: Ann. Phytopath. Soc. Japan, 47, 680-684 (1981). 